\title{
Practice and Exploration of Entrepreneurship Education System to Promote College Students' Employment and Entrepreneurship
}

Yuli Zhang

Beihua University, Jilin 132013, Jilin, China.

Abstract: In recent years, the society and colleges and universities pay more and more attention to the development of entrepreneurship education. Entrepreneurship education greatly promotes the development of college students' employment and entrepreneurship. It is the deepening and development of quality education and innovation education, and is also an important way for higher education to meet the needs of current education development and realize its own reform and development. Therefore, this paper analyzes the necessity of entrepreneurship education, studies the actual situation of college Students' employment and entrepreneurship, and analyzes the existing problems, as well as explores the effective countermeasures based on the reminder function of college students' entrepreneurship and employment in the new period.

Keywords: Entrepreneurship Education System; College Students; Employment and Entrepreneurship

In recent years, the number of college graduates is increasing, and the problem of college students' employment has become an important factor that hinders the development of education and social stability and progress. Entrepreneurship education is one of the important ways to relieve employment pressure. Therefore, it is urgent to carry out entrepreneurship education and explore a distinctive entrepreneurship education system.

\section{The necessity of entrepreneurship education}

\subsection{Entrepreneurship education is conducive to promoting social development}

Under the market economy system, knowledge and talents are the necessary driving force for social development. The competition between the market and enterprises is also the competition for talents in essence. The innovation spirit and ability determine the necessary ability and quality of talents in the new period. Therefore, in the process of education in the new period, we need to pay attention to innovation and entrepreneurship education to adapt to the development of the times, so as to cultivate more high-quality builders and successors for the society, replace employment with entrepreneurship, and relieve employment pressure. Based on this, in order to solve the employment problem of college students, the state has issued a policy to encourage college graduates to start their own businesses. At the same time, colleges and universities need to actively carry out entrepreneurship education for college students, so as to improve their entrepreneurial awareness and ability, promote their future employment and contribute to social development and progress.

\subsection{Entrepreneurship education is conducive to the development of students themselves}

There are some wrong tendencies in the traditional concept of employment. We must correct the incorrect employment concept of college students and avoid imprisoning the possibility of their own development. Contemporary college students should be good at discovering their own advantages, tapping their own potential and increasing employment opportunities. This requires college students not only to improve themselves by learning knowledge, but also to improve their social adaptability. To carry out entrepreneurship education is conducive to improve students' comprehensive ability, fully tap the innovation and

Copyright $(2020$ Yuli Zhang

doi: 10.18686/ahe.v4i10.2947

This is an open-access article distributed under the terms of the Creative Commons Attribution Non-Commercial License (http://creativecommons. org/licenses/by-nc/4.0/), which permits unrestricted non-commercial use, distribution, and reproduction in any medium, provided the original work is properly cited. 
entrepreneurship potential of college students, and realize the maximization of their own value, thus forming a virtuous circle. Han Yu pointed out in his "Teacher Said" article: "teacher is the one, who preaches knowledge and dispels doubts." In addition to teaching people how to behave, the biggest responsibility of education is to teach students the ability to survive and do things. The positive and effective development of entrepreneurship education fully reflects this point.

\section{The current situation of entrepreneurship education for college Students}

\subsection{The unreasonable proportion of theory and practice}

Nowadays, entrepreneurship education in colleges and universities is still in the initial stage of practice, there are some deficiencies in concept and practice. In addition, entrepreneurship education carried out by some colleges and universities in China is still in the primary stage of development, and the main fields and modules involved are relatively limited. In the existing pilot colleges of entrepreneurship education, its form is too single, too limited to the teaching mode of imparting knowledge, focusing on entrepreneurship theory education and ignoring the corresponding practical guidance.

\subsection{Lack of entrepreneurial education teachers and curriculum resources}

From the analysis of the teaching staff for entrepreneurship education in some colleges and universities, there is a general lack of entrepreneurship education teachers and professional guidance in colleges and universities, and there is no professional system in the theoretical knowledge teaching and practice guidance for entrepreneurship education. The vast majority of academic expert teachers are knowledgeable, but they do not understand the operation, development and management of enterprises in the process of entrepreneurship, and lack the ability to guide entrepreneurship practice. Therefore, in the teaching they only tend to the theory teaching, and ignore the actual operation process of the enterprise as well as other practical operation links, resulting in the lack of interest in the course.

From the perspective of the construction of entrepreneurship curriculum system in related universities, although some colleges and universities have opened this course, the lack of standardization and systematization of the curriculum, the lagging behind of the preparation of teaching materials for entrepreneurship education, and the imperfection of the content, have affected the actual teaching.

\subsection{Lack of a perfect service guarantee system of entrepreneurship education}

In order to carry out entrepreneurship education for college students, it is necessary to have relevant guarantee system support, such as: system and laws and regulations guarantee, policy guarantee and fund guarantee, etc. However, the current social support and guarantee system of entrepreneurship education is not perfect, which is not conducive to the sustainable development of college Students' innovation and entrepreneurship education. Specifically, it can be manifested as the following five points: first, the country lacks legal basis to encourage students to start their own businesses; second, the government has not really established a complete set of funding system for college students' employment and entrepreneurship; third, the organization of entrepreneurship education in colleges and universities is not perfect; fourth, the system of guaranteeing entrepreneurship education is not perfect; fifth, the practical facilities of entrepreneurship education are not complete.

\section{The effective countermeasures of constructing the system of entrepreneurship education}

\subsection{Innovating educational concept and promoting entrepreneurial enthusiasm}

In order to promote the effective implementation of entrepreneurship education in college students' education, teachers of relevant courses should deepen the penetration of entrepreneurship education concept and enhance the attention of teachers and students to entrepreneurship education. From the aspect of colleges and universities, we should promote the transformation of school running ideas, let students combine comprehensive quality education with professional education, and create a compound talent training system of higher education in the new era. From the perspective of college students, they should enhance their awareness of entrepreneurship, actively adapt to social changes, in order to establish a correct outlook on career choice and employment, and enhance their entrepreneurial ability and literacy, as well as social competitiveness in the future. In addition, in entrepreneurship education, we should take practice teaching as the starting point and combine theory with practice. On the one hand, under the guidance of theory to guide practice, learning for application; on the other hand, let students put forward and solve problems, and summarize theory in practice to stimulate their interest in learning.

\subsection{Setting up a professional teaching staff and attaching importance to the curriculum construction for entrepreneurship education}

He construction of teacher staffs for college students' entrepreneurship also affects the quality of entrepreneurship 
education to a certain extent. Therefore, we should pay attention to the construction of high-quality entrepreneurship education teachers. First of all, colleges and universities can select some excellent teachers and carry out professional training, so that they can understand and deepen the knowledge of entrepreneurship education and teaching. Secondly, relevant seminars and lectures can be carried out regularly to enable teachers to exchange experience in entrepreneurship education, so as to improve their entrepreneurship education level and related teaching skills. Finally, we can create conditions to provide more learning and training opportunities for teachers while introducing external teachers, so that they can timely update their ideas with educational concepts, update teaching contents, and enhance the intrinsic value and practical ability of entrepreneurship education, so as to strive to build a "double qualified" teaching team. In addition, in terms of curriculum setting, entrepreneurship education knowledge is taken as the basic course content, which is taught by full-time teachers in the form of compulsory courses; optional courses of entrepreneurship education can also be set up to broaden students' horizons; some well-known entrepreneurs and outstanding entrepreneurial graduates can be invited to give lectures and speeches on entrepreneurship education in colleges and universities, so as to further strengthen the guidance of entrepreneurial students.

\subsection{Improving the guarantee mechanism and laying the foundation of entrepreneurship education}

For the development of entrepreneurship education for college students, relevant education departments and financial department should give some support to provide a reliable guarantee for entrepreneurship education in colleges and universities, in order to lay a solid foundation for entrepreneurship education. For example, the establishment of college students' venture fund, the formulation of "College Students' Venture Fund Management Regulations", to promote the use of scientific, reasonable and efficient fund. Actively attract for social organizations, public welfare groups, enterprises and institutions as well as individuals to set up venture funds for college students, and support college students to start their own businesses in various forms. Vigorously support college graduates to start their own businesses, so that they can fully enjoy the government's financial assistance. At the same time, in order to achieve sustainable development of entrepreneurship education in colleges and universities, in addition to its own and government funding, it should also make full use of the school enterprise cooperation development alliance, establish a multi-party cooperation platform, and strive for the support of social and enterprise funds.

\section{Conclusion}

In summary, under the background of the popularization of higher education and the increasingly severe employment situation, self employment has become a new way for college graduates to obtain employment. Entrepreneurship education takes the spirit of innovation and creative ability as the core and aims at cultivating creative talents, which meets the requirements of the development of the times for talents. Although the entrepreneurship education of college students in China is still in the initial stage and the theoretical system is not perfect, it is urgent to develop entrepreneurship education for college students in combination with the world education situation and development prospects. Therefore, colleges and universities should combine with the reality, change the education concept, and pay attention to the cultivation of contemporary college students' entrepreneurial consciousness, in order to build high-quality entrepreneurial education teachers, establish and improve the curriculum system and service guarantee system of entrepreneurship education, and improve the effect of entrepreneurship education for college students

\section{References}

1. Jin M. The current situation and countermeasures of entrepreneurship and employment education system in normal universities in China. Education Theory Research 2018; (24): 118-119.

2. Qu D. Construction and implementation strategy of entrepreneurship education system in colleges and universities. Northeast Normal University; 2007.

3. Wang Q. On the innovation and entrepreneurship education of college students. Journal of Ningbo Institute of Education 2015; (4): 9-11.

4. Zhou Q. Analysis and construction of entrepreneurship education system in China's universities. Journal of Shandong Radio and TV University 2016; (4): 78-81.

5. Yang Y. Construction of entrepreneurship education system for college students. Higher Education 2016; (1): 57-58.

6. Liang W. On the construction and improvement of college students' entrepreneurship education system. School Party Construction and Ideological Education 2014; (11): 67-76. 